\title{
INFLUENCE OF RESERVOIRS ON THE CONCENTRATION OF NUTRIENTS IN THE WATER OF MOUNTAIN RIVERS
}

\author{
WPŁYW ZBIORNIKÓW RETENCYJNYCH NA KONCENTRACJE \\ NUTRIENTÓW W WODACH RZECZNYCH OBSZARÓW GÓRSKICH
}

\begin{abstract}
The aim of the analysis was to demonstrate the role of reservoirs in shaping nutrient content (nitrates $\mathrm{NO}_{3}{ }^{-}$and phosphates $\mathrm{PO}_{4}{ }^{3-}$ as well as ammonia $\mathrm{NH}_{4}{ }^{+}$) in the waters of mountain rivers. Three Carpathian rivers with reservoirs in their courses were selected for the study: the Ropa River (Klimkowka reservoir), the Dunajec River (the Czorsztyn-Sromowce Wyzne reservoir complex) and the Raba River (Dobczyce reservoir). The basic criteria for the selection of the study objects for the investigation were: similar hydrological regime of the rivers and diverse parameters and functions of the storage reservoirs. The analysis of nutrient concentration was based on a long-term series of measurements (2004-2013). The reservoirs investigated generally contribute to an increase in nitrates in the rivers flowing below the reservoirs in particular months. The role of reservoirs in shaping phosphate and ammonia levels was not as evident as in the case of nitrates. The reservoirs are merely one of numerous factors that contribute to nutrient levels in the water of the mountains rivers. In the light of the analysis of nutrient concentrations in the surface water tested, it may be concluded that the reservoirs do not cause a clear and permanent deterioration of river water quality.
\end{abstract}

Keywords: nutrients, water quality, reservoirs, mountain rivers, Carpathians

\section{Introduction}

Reservoirs play a very important role in the geochemical cycling of elements and influence the chemical composition of the river system [1]. According to Dumnicka et al [2], the differences in the impact of storage reservoirs on the chemical composition of river waters result from various locations of the outlet, depth of the reservoir, frequency of water exchange, and the degree of water pollution. The physicochemical properties of the water running out of the reservoir reflect the quality of the water entering it as well as the biotic and abiotic phenomena in the reservoir.

\footnotetext{
${ }^{1}$ Institute of Geography and Spatial Organization, Polish Academy of Sciences, Research Station in Szymbark, 38-311 Szymbark 430, Poland

${ }^{2}$ Department of Geoenvironmental Research, Institute of Geography and Spatial Organization, Polish Academy of Sciences, ul. św. Jana 22, 31-018 Kraków, Poland

${ }^{3}$ Department of Environment Protection and Modelling, The Jan Kochanowski University, ul. Świętokrzyska 15G, 25-406 Kielce, Poland

*Corresponding author: mkijowska@zg.pan.krakow.pl
} 
According to Palmer and O'Keeffe [1], small dams generally cause low-intensity chemical changes, which recover within a few kilometres, but larger dams cause larger disturbances which take up to $30 \mathrm{~km}$ to recover. The downstream effects of impoundments with low-level outlets were more severe than water releases from the surface. The studies conducted in various regions of the world indicate that large reservoirs supplied with moderately and poorly polluted tributaries improve the quality of water [3, 4]. Reservoirs can temporarily retain even $90 \%$ of the total amount of inflowing matter and biogenic substances associated with it. Proper assessment of the influence of reservoirs on the quality of water in rivers flowing below the reservoir requires an analysis of the quality of water that supplies it, which results, among others, from the manner of water and sewage management in the catchment area [5].

In the world literature, the studies on the influence of storage reservoirs on the chemical composition (including nutrients concentrations) of rivers are focused both on single and numerous reservoirs localised in various regions, diversified in terms of physical and geographical characteristics [4, 6-12]. Mountain regions show high temporal and spatial diversification of all hydrological processes [13-15]. Therefore, disturbances of the hydrochemical regime in mountain rivers caused by the presence of reservoirs may bring about environmental effects that may be more unpredictable than in less diversified terrains.

The aim of the analysis conducted was to demonstrate the role of Carpathian reservoirs in shaping nutrient content (nitrates $\mathrm{NO}_{3}{ }^{-}$and phosphates $\mathrm{PO}_{4}{ }^{3-}$ as well as ammonia $\mathrm{NH}_{4}{ }^{+}$) in the waters of mountain rivers. The analysis presents temporal and spatial dynamics of nutrient concentration in water stored in three selected reservoirs and in rivers flowing above and below them. The basic criteria for the selection of the objects for the investigation were: similar hydrological regime of the rivers and diverse parameters and functions of the storage reservoirs. This enabled the synthesis of the direction and degree of hydrochemical changes in Carpathian rivers caused by dams located in their courses.

\section{Methods and area of investigation}

Three Carpathian rivers with reservoirs in their courses were selected for the study: the Ropa River (Klimkowka reservoir), the Dunajec River (the Czorsztyn-Sromowce Wyzne reservoir complex) and the Raba River (Dobczyce reservoir), (Fig. 1, Table 1).

The analysed courses of the Carpathian rivers are localised in the region of the Outer Western Carpathians. From the geological point of view, these mountains consist of several nappes moved there from the south and composed of Upper Cretaceous and Paleogene sandstones, conglomerates and shales (so-called Carpathian flysch). The hydrological regime of Carpathian rivers is characterised by considerable annual and slight multi-annual changeability of discharge. Low discharge is observed mainly in autumn and winter whereas high discharge occurs in spring and summer. The rivers selected are situated in the basin area of the Upper Vistula River and are characterised by considerable water reserves, irregularly distributed in time and space, as well as a large flooding potential and intense river bed erosion processes.

Changes in the concentrations of nitrates, phosphates and ammonia in the reservoirs discussed as well as in rivers above and below their locations were determined on the basis of samples collected in measuring points belonging to the Polish network of the Voivodship Inspectorates for Environmental Protection (in Polish: WIOS) in Krakow, Poland. The data used in the study encompass the period from 2004 to 2013. 


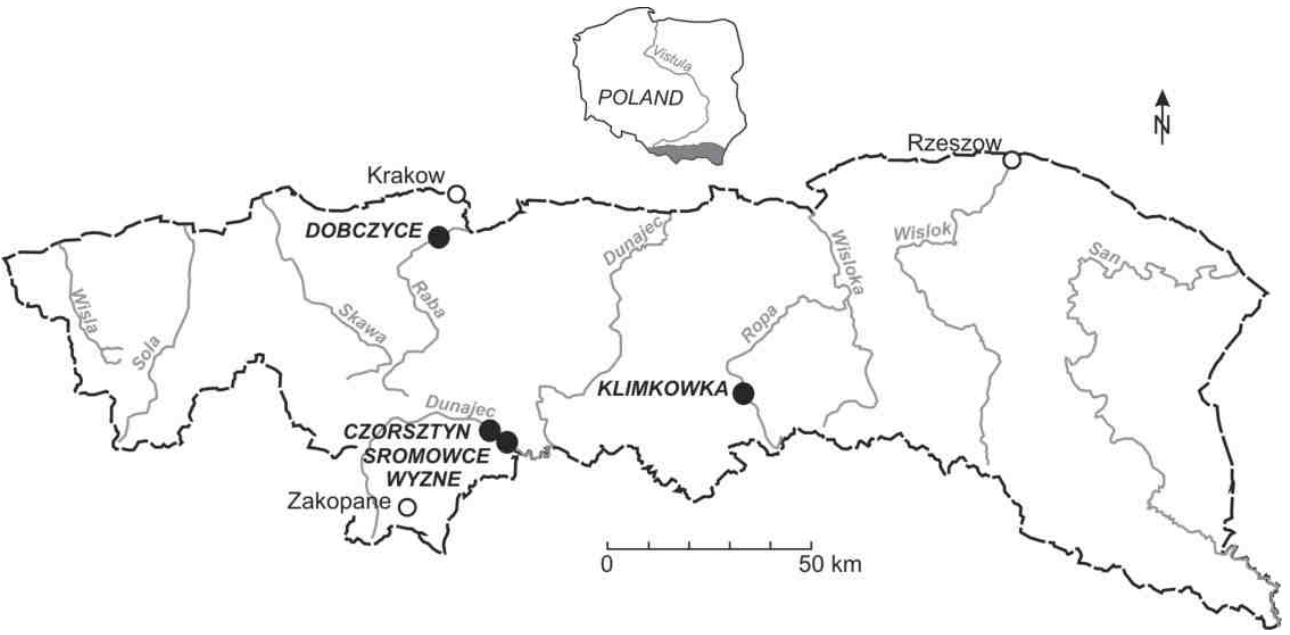

Fig. 1. Localization of the studied reservoirs and rivers in the Polish Carpathians

Characteristics of the studied Carpathian reservoirs

\begin{tabular}{|c|c|c|c|c|c|c|c|c|}
\hline Reservoir & River & $\begin{array}{l}\text { Catchment } \\
\text { area }\left[\mathbf{k m}^{2}\right]\end{array}$ & $\begin{array}{l}\text { Capacity } \\
{\left[\mathrm{mln} \mathrm{m}^{3}\right]}\end{array}$ & $\begin{array}{c}\text { Depth } \\
\text { [m] }\end{array}$ & $\begin{array}{c}\text { The area } \\
{\left[\mathrm{km}^{2}\right]}\end{array}$ & $\begin{array}{l}\text { Year of } \\
\text { creation }\end{array}$ & Functions" & $\begin{array}{l}\text { Schindler } \\
\text { coefficient }\end{array}$ \\
\hline Czorsztyn & Dunajec & 1147 & 234.5 & 50.0 & 11.0 & 1997 & E, F, L & 4.9 (II) \\
\hline Sromowce & Dunajec & 1287 & 7.5 & 8.5 & 0.9 & 1994 & $\mathrm{~F}, \mathrm{~L}$ & 170.5 (III) \\
\hline Dobczyce & Raba & 768 & 127.0 & 28.0 & 10.7 & 1986 & $\mathrm{~W}, \mathrm{~F}, \mathrm{~L}$ & 5.6 (II) \\
\hline Klimkowka & Ropa & 210 & 43.5 & 30.0 & 3.1 & 1994 & $F, L, E$ & 4.8 (II) \\
\hline
\end{tabular}

*E - energy, F - flood protection, L - flow leveling, W - drinking water supply

The data collected by WIOS is a result of the only multi-annual hydrochemical measurements conducted in reservoirs and rivers in their immediate vicinity. However, the series of data obtained were not continuous in time and not all nutrients were tested in individual years. Nevertheless, a ten-year series of measurements was sufficient to present annual dynamics of nutrients in the selected rivers and reservoirs in a reliable way.

The selected sites for measuring the bodies of water are localised:

- $\quad$ in the Raba River above Dobczyce reservoir in Myslenice ( $0.5 \mathrm{~km}$ above reservoir), in

Dobczyce reservoir and below the reservoir in the Dobczyce town $(0.5 \mathrm{~km})$;

- in the Ropa River above Klimkowka reservoir in Uscie Gorlickie $(1.5 \mathrm{~km})$, in

Klimkowka reservoir and below the reservoir in the Szymbark village $(13.5 \mathrm{~km})$;

- $\quad$ in the Dunajec River above the Czorsztyn-Sromowce Wyzne reservoir complex in

Harklowa village $(5.0 \mathrm{~km})$, in Czorsztyn and Sromowce Wyzne reservoirs as well as

below the reservoirs in Cerveny Klastor $(7.5 \mathrm{~km})$.

The samples for the laboratory analysis of the chemical composition were collected each month. The winter season was an exception because ice cover on reservoirs frequently prevented sampling. The collected data base enabled determination of the mean, minimum and maximum monthly and annual concentrations of the nutrients tested in the period of investigation in given measuring points. The values obtained were compared with the Regulation of the Minister of the Environment of 21 July 2016 on the classification of 
ecological status, ecological potential and chemical status of surface waterbody [16]. The regulation in accordance with the requirements of the European Union. For this purpose, the Schindler's index was calculated as well. It determines the role of the catchment area in shaping qualitative parameters of lentic water. The usability of water inflowing to and outflowing form the reservoirs was determined by comparing the indicators tested with the limit values that need to be fulfilled in order to enable fish dwelling [17]. Moreover, the waters sensitive to contamination with nitrogen compounds of agricultural origin were indicated [18].

Furthermore, in order to determine the role of the storage reservoirs in shaping the ecochemical status of the rivers analysed, water samples were collected from the reservoirs and rivers above and below their localisations in individual seasons in 2011-2012 (20 Aug 2011, 2 Nov 2011, 23 Feb 2012, 10 Apr 2012). The chemical composition was analysed with the use of a DIONEX ICS-3000 ion chromatograph. The tests enabled the calculation of the indicator of water ecochemical status, ie the volume of acid neutralising capacity, ANCaq (in $\left[\mu \mathrm{Eq} \cdot \mathrm{dm}^{-3}\right]$ ) $[18,19]$.

The data collected were analysed statistically with the use of a STATISTICA 10 system in order to specify the levels of statistical significance between the parameters tested. The collected variables were initially analysed with the use of the Shapiro-Wilk test in order to specify the agreement of the data with the normal distribution. In the situation when the requirements concerning parametric tests were not met, the non-parametric $\mathrm{U}$ Mann-Whitney test was applied. The analysis included the mean monthly values from the period of 2004-2013.

\section{Results and discussion}

\section{Temporal and spatial dynamics of nutrients in Carpathian rivers and storage reservoirs}

\section{Dunajec River and Czorsztyn-Sromowce Wyzne reservoir complex}

Nitrates $\left(\mathrm{NO}_{3}{ }^{-}\right)$are ones of the basic nutrients that influence pollution of surface water. They originate from sewage, runoff from fertilised soil, rainwater and processes of biochemical degradation of organic nitrogen compounds. The commonly used nitrogen fertilisers considerably contribute to an increase of nitrate concentration in water. Nitrogen compounds are necessary for aquatic organisms. Natural water reservoirs exhibit high tolerability to nitrates. However, over-fertilisation of water with nitrogen and phosphorus compounds causes an intense growth of aquatic plants. This leads to overgrowing (eutrophication) of water reservoirs. Excessive amounts of organic matter lead, in turn, to excessive oxygen use. As a consequence, fish die out and mineralisation processes are inhibited.

The analysis conducted revealed that the mean monthly content of nitrates $\left(\mathrm{NO}_{3}{ }^{-}\right)$in 2004-2013 in the Dunajec River above and below the Czorsztyn-Sromowce Wyzne reservoir complex did not exceed the limit value for I water class (purity class), ie $9.2 \mathrm{mg} \mathrm{NO}{ }_{3}^{-} \mathrm{mg} \cdot \mathrm{dm}^{-3}$ (Table 2, Fig. 2) [16]. The high mean value amounted to $5.4 \mathrm{mg} \cdot \mathrm{dm}^{-3}$ was noticed in Czorsztyn reservoir in April. In winter months (January-March and November-December), the concentrations of nitrates were higher above than below the reservoir complex. An inverse correlation was observed in the summer season. The winter 
season was also characterised by the highest nitrate concentrations in all measuring sites. One of the more important factors that influence nitrate levels is land use [20].
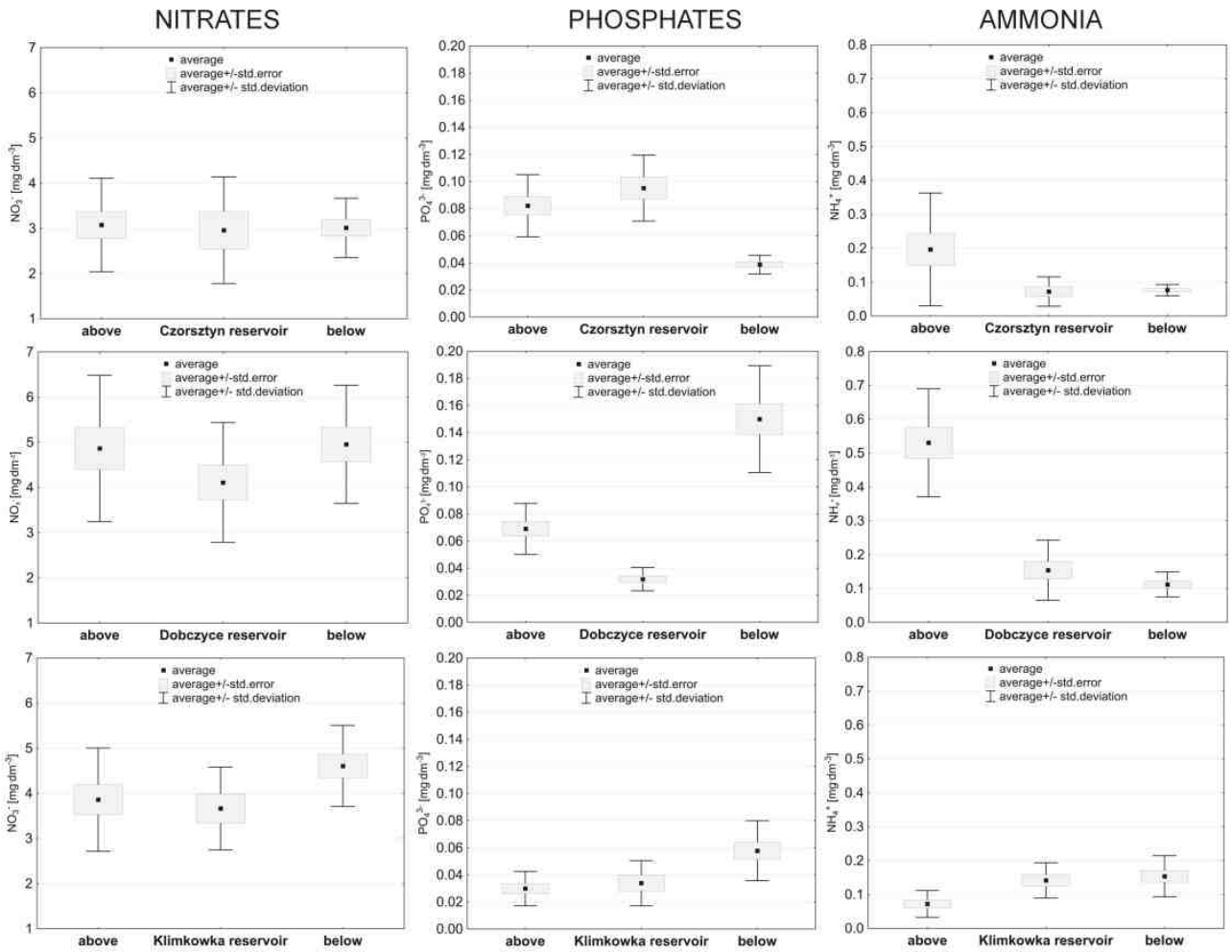

Fig. 2. Content of nutrients in the reservoirs and Carpathian rivers selected for the analysis

As in other regions of the Polish Carpathians, a decrease in arable land area and an increase in grassland area is observed also in the Upper Dunajec catchment. The area of arable land in the Upper Dunajec region has decreased by approximately $17 \%$ since the beginning of the 1990s. At the same time, it is observed that wastelands as well as developed lands and infrastructural sites have been increasing in area. In the Upper Dunajec catchment, their area has increased on average by $4 \%$. The analysis of the mean annual nitrate values in the past decade indicates a considerable nitrate level decline in the Dunajec River above and below the Czorsztyn-Sromowce Wyzne reservoir complex. This indicates that the supply of nitrate contaminants of agricultural origin in the Upper Dunajec catchment has been visibly reduced over the past years. The mean annual nitrate values noted above the Czorsztyn-Sromowce Wyzne complex exceeded $5.0 \mathrm{mg} \cdot \mathrm{dm}^{-3}$ and fell within the range from $6.5 \mathrm{mg} \cdot \mathrm{dm}^{-3}$ in 2005 to $4.9 \mathrm{mg} \cdot \mathrm{dm}^{-3}$ in 2012 . In the Dunajec River below the impoundments, this range was lower: from $5.0 \mathrm{mg} \cdot \mathrm{dm}^{-3}$ in 2005 to $3.3 \mathrm{mg} \cdot \mathrm{dm}^{-3}$ in 2012. Such a state could also result from the dynamic development of sanitary infrastructure in this period. The average length of sanitary installations in the Upper Dunajec catchment increased nearly 8 times over the last 30 years. 
The concentration of nitrates did not exceed $10 \mathrm{mg} \cdot \mathrm{dm}^{-3}$. This in the admissible limit value above which the phenomenon of eutrophication may occur [18].

The second most important nutrients that contribute to the quality of surface water are phosphates $\left(\mathrm{PO}_{4}{ }^{3-}\right)$. As nitrogen compounds, phosphates belong to the basic biogenic factors that contribute to the development of algae. The source of phosphorus in surface water is the breakdown of organic matter (plants or animals) and agriculture, mainly phosphorus fertilisers, as well as contaminants in industrial wastewater.

The mean monthly content of phosphates in 2004-2013 reached the highest values in Czorsztyn reservoir (Fig. 2, Table 2), except for September. The highest level was noted in March and July (1.14 and $0.12 \mathrm{mg} \cdot \mathrm{dm}^{-3}$ respectively). High phosphate concentrations were also noted above the Czorsztyn-Sromowce Wyzne complex (ranging from $0.12 \mathrm{mg} \cdot \mathrm{dm}^{-3}$ in February to $0.04 \mathrm{mg} \cdot \mathrm{dm}^{-3}$ in November). In Sromowce Wyzne balancing reservoir, the mean monthly phosphate concentrations were considerably lower than in the main reservoir (they ranged from $0.05-0.02 \mathrm{mg} \cdot \mathrm{dm}^{-3}$ ). This contributed to lower levels of this nutrient in the river below the reservoir complex (Fig. 2). In the period investigated, the mean annual phosphate values did not demonstrate the downward tendency observed in the case of nitrates. The measuring site localised below the Czorsztyn-Sromowce Wyzne complex was an exception - a visible downward tendency was observed there $(R=0.7199, p<0.05)$. The highest mean annual values in the period 2004-2013 were noted above the reservoir complex (mean $0.08 \mathrm{mg} \cdot \mathrm{dm}^{-3}$ ), but they did not exceed the admissible limit values for class I water $\left(0.2 \mathrm{mg} \cdot \mathrm{dm}^{-3}\right)$.

The content of phosphates in the river above and below the reservoir complex amounted to $0.25 \mathrm{mg} \cdot \mathrm{dm}^{-3}$. This in the admissible limit value above which the phenomenon of eutrophication may occur [18]. In lentic water, the limit value is $0.1 \mathrm{mg} \cdot \mathrm{dm}^{-3}$ (growing season). In Czorsztyn reservoir, the mean monthly levels in July exceeded this value, which might indicate that eutrophication may occur.

Another nutrient analysed in the context of water pollution is ammonia. It can be found in surface water and originates from biochemical breakdown of organic nitrogen compounds from plants and animals, or from industrial wastewater or domestic sewage. This form of nitrogen is freely absorbed by autotrophs and therefore is the main source of nutrients for the phytoplankton.

The highest average monthly concentrations of ammonia were noted in the water entering Czorsztyn reservoir. In February, the mean monthly ammonia levels reached $0.58 \mathrm{mg} \cdot \mathrm{dm}^{-3}$, which indicates that the limit for I water class was exceeded $\left(1.0 \mathrm{mg} \cdot \mathrm{dm}^{-3}\right)$. Increased concentrations in the winter and early spring result from the fact that ammoniacal nitrogen compounds are not absorbed by plants yet and, additionally, low temperatures constrain biochemical processes. Low levels of this nutrient were noted both in Czorsztyn reservoir and in the river below the Czorsztyn-Sromowce Wyzne complex. In Sromowce Wyzne balancing reservoir, the values of this parameter were higher than in the main reservoir. This is due to its lower size. The highest average annual concentrations of ammonia in 2004-2013 were noted in the Dunajec River above the reservoir complex. The values ranged from $0.31 \mathrm{mg} \cdot \mathrm{dm}^{-3}$ (2004) to $0.10 \mathrm{mg} \cdot \mathrm{dm}^{-3}$ (2008). Considerably lower values were observed in the water running out of the impoundments: from $0.10 \mathrm{mg} \cdot \mathrm{dm}^{-3}$ (2004) to $0.05 \mathrm{mg} \cdot \mathrm{dm}^{-3}$ (2013). The mean annual ammonia concentrations below the reservoir complex are characterised by a visible downward tendency $(R=0.6994$, $p<0.05)$, as with phosphates. As other nutrients, a part of ammonia is retained in the reservoir complex, which contributes to the improved quality of outflowing water. In all 
measuring sites, ammonia concentrations did not exceed the admissible limits for I surface water class.

Table 2

Selected statistic parameters of nutrients concentration in the water above, below and in the reservoirs (period 2004-2013)

\begin{tabular}{|c|c|c|c|c|c|}
\hline \multirow{2}{*}{ Localization } & \multirow{2}{*}{$\begin{array}{c}\text { Statistic parameters } \\
\text { of concentration }\end{array}$} & \multirow{2}{*}{ Unit } & NITRATE & PHOSPHATE & AMMONIA \\
\hline & & & $\mathrm{NO}_{3}^{-}$ & $\mathrm{PO}_{4}{ }^{3-}$ & $\mathrm{NH}_{4}{ }^{+}$ \\
\hline \multirow{3}{*}{$\begin{array}{l}\text { Dunajec River above } \\
\text { reservoirs }\end{array}$} & $\min -\max$ & \multirow{2}{*}[\mathrm{mg}\cdot\mathrm{dm}^{-3}]{} & $0.03-12.00$ & $0.03-0.40$ & $0.03-1.20$ \\
\hline & mean & & 3.08 & 0.08 & 0.20 \\
\hline & SD & - & 1.08 & 0.55 & 0.72 \\
\hline \multirow{3}{*}{ Czorsztyn reservoir } & $\min -\max$ & \multirow{2}{*}[\mathrm{mg}\cdot\mathrm{dm}^{-3}]{} & $0.89-6.20$ & $0.03-0.14$ & $0.03-0.18$ \\
\hline & mean & & 2.96 & 0.10 & 0.07 \\
\hline & $\mathrm{SD}$ & - & 0.57 & 0.03 & 0.02 \\
\hline \multirow{3}{*}{$\begin{array}{l}\text { Sromowce Wyzne } \\
\text { reservoir }\end{array}$} & $\min -\max$ & \multirow{2}{*}[\mathrm{mg}\cdot\mathrm{dm}^{-3}]{} & $0.04-7.10$ & $0.02-0.08$ & $0.03-0.18$ \\
\hline & mean & & 2.93 & 0.03 & 0.10 \\
\hline & $\mathrm{SD}$ & - & 1.53 & 0.01 & 0.02 \\
\hline \multirow{3}{*}{$\begin{array}{l}\text { Dunajec River below } \\
\text { reservoirs }\end{array}$} & $\min -\max$ & \multirow{2}{*}[\mathrm{mg}\cdot\mathrm{dm}^{-3}]{} & $0.01-7.96$ & $0.02-0.21$ & $0.03-0.18$ \\
\hline & mean & & 3.01 & 0.04 & 0.08 \\
\hline & SD & - & 1.82 & 0.02 & 0.05 \\
\hline \multirow{3}{*}{$\begin{array}{l}\text { Raba River above } \\
\text { reservoir }\end{array}$} & $\min -\max$ & \multirow{2}{*}[\mathrm{mg}\cdot\mathrm{dm}^{-3}]{} & $0.22-15.81$ & $0.01-0.36$ & $0.03-2.22$ \\
\hline & mean & & 4.87 & 0.07 & 0.53 \\
\hline & SD & - & 1.89 & 0.06 & 0.50 \\
\hline \multirow{3}{*}{ Dobczyce reservoir } & $\min -\max$ & \multirow{2}{*}[\mathrm{mg}\cdot\mathrm{dm}^{-3}]{} & $1.33-9.61$ & $0.01-0.14$ & $0.03-0.73$ \\
\hline & mean & & 4.11 & 0.03 & 0.15 \\
\hline & $\mathrm{SD}$ & - & 1.29 & 0.02 & 0.09 \\
\hline \multirow{3}{*}{$\begin{array}{c}\text { Raba River below } \\
\text { reservoir }\end{array}$} & $\min -\max$ & \multirow{2}{*}[\mathrm{mg}\cdot\mathrm{dm}^{-3}]{} & $1.81-8.40$ & $0.03-0.46$ & $0.03-0.73$ \\
\hline & mean & & 4.96 & 0.15 & 0.10 \\
\hline & $\mathrm{SD}$ & - & 1.11 & 0.06 & 0.06 \\
\hline \multirow{3}{*}{$\begin{array}{l}\text { Ropa River above } \\
\text { reservoir }\end{array}$} & $\min -\max$ & \multirow{2}{*}[\mathrm{mg}\cdot\mathrm{dm}^{-3}]{} & $1.05-7.32$ & $0.02-0.13$ & $0.01-0.22$ \\
\hline & mean & & 3.86 & 0.03 & 0.07 \\
\hline & $\mathrm{SD}$ & - & 0.57 & 1.86 & 1.20 \\
\hline \multirow{3}{*}{ Klimkowka reservoir } & $\min -\max$ & \multirow{2}{*}[\mathrm{mg}\cdot\mathrm{dm}^{-3}]{} & $2.13-6.60$ & $0.02-0.15$ & $0.05-0.28$ \\
\hline & mean & & 3.66 & 0.05 & 0.14 \\
\hline & SD & - & 1.19 & 0.25 & 0.43 \\
\hline \multirow{3}{*}{$\begin{array}{c}\text { Ropa River below } \\
\text { reservoir }\end{array}$} & $\min -\max$ & \multirow{2}{*}[\mathrm{mg}\cdot\mathrm{dm}^{-3}]{} & $2.01-10.18$ & $0.02-0.69$ & $0.01-1.04$ \\
\hline & mean & & 4.69 & 0.06 & 0.17 \\
\hline & $\mathrm{SD}$ & - & 0.32 & 0.96 & 0.81 \\
\hline
\end{tabular}

"min - minimum concentration during the period of observation, max - maximum concentration, SD - standard deviation

Based on the statistical analysis conducted with the use of the non-parametric U Mann-Whitney test, it was concluded that there is a statistically significant difference $(p<0.01)$ in phosphate content between Czorsztyn reservoir and samples collected below it (Table 3). It was also demonstrated that the differences in the content of ammonium ions between Czorsztyn reservoir and sites localised above it are statistically significant. However, no statistically significant differences were found in the content of nitrate ions.

\section{Raba River and Dobczyce reservoir}

According to Balcerzak [21], agricultural farms are a major hazard for the quality of surface water in the catchment area of Dobczyce reservoir. Septic tanks that are not tight are of particular concern since they enable impurities to permeate to ground water and 
subsequently to nearby watercourses. Kopacz and Twardy [22] report that arable lands, which constitute from 36 to $64 \%$ of the total area, are predominant in the catchment of Dobczyce reservoir. In the past 25 years, a reduction in the arable area was observed in the catchment of the Upper Raba (as in other regions of the Polish Carpathians). In 1981, arable land constituted $44 \%$ of the agricultural land whereas in 2005 , the percentage amounted to merely $27 \%$.

As with the Dunajec River, the mean monthly nitrate concentrations in the Raba River in the winter season were higher above Dobczyce reservoir than below it. In this period, the concentrations did not exceed the admissible values for I water class. From April to August, nitrate concentrations were higher in the reservoir and in the river below the dam than in the Raba River above the reservoir. The mean monthly nitrate concentrations below the dam ranged from $3.89 \mathrm{mg} \cdot \mathrm{dm}^{-3}$ (December) to $7.18 \mathrm{mg} \cdot \mathrm{dm}^{-3}$ (April), and in the reservoir: from $2.50 \mathrm{mg} \cdot \mathrm{dm}^{-3}$ (September) to $6.2 \mathrm{mg} \cdot \mathrm{dm}^{-3}$ (February; Table 2). As far as the mean annual nitrate concentrations are concerned, the statistically significant upward tendency $(R=0.6923, p<0.05)$ has been observed in the past decade only above the Dobczyce reservoir. Since 2007, Dobczyce reservoir has shown lower annual nitrate concentrations than the river above and below its localisation.

The concentration of nitrates did not exceed $10 \mathrm{mg} \cdot \mathrm{dm}^{3}$. This in the admissible limit value above which the phenomenon of eutrophication in the flowing water may occur [18].

The highest average monthly levels of phosphates were noted in the Raba River below Dobczyce reservoir $\left(0.03-0.46 \mathrm{mg} \cdot \mathrm{dm}^{-3}\right.$; Table 2$)$. They were frequently 7 times higher than the values recorded at the remaining measuring stations (in the reservoir and in the river above it). In June and September, these values exceeded $0.2 \mathrm{mg} \cdot \mathrm{dm}^{-3}$. Above Dobczyce reservoir and in the reservoir itself, phosphate concentrations were considerably lower (0.03-0.10 and $0.01-0.05 \mathrm{mg} \cdot \mathrm{dm}^{-3}$ respectively). In the spring, when the growing season had begun, a decline in phosphate content was observed in the reservoir. In the summer, however, an increase in phosphate levels and a simultaneous decrease in nitrate concentrations contributed to the deterioration of the quality of water. In 2004-2013, the mean annual phosphate concentrations did not exceed the threshold admissible for I water class $\left(0.2 \mathrm{mg} \cdot \mathrm{dm}^{-3}\right)$. It should be noted that the highest mean phosphate concentrations were recorded in the Raba River below the reservoir: from 0.12 (2007) to $0.18 \mathrm{mg} \cdot \mathrm{dm}^{-3}$ (2009), and the lowest - in the reservoir itself: from 0.02 (2005) to $0.07 \mathrm{mg} \cdot \mathrm{dm}^{-3}(2010)$.

The phosphate concentrations in the Raba River and Dobczyce reservoir did not exceed the admissible limits above which the phenomenon of eutrophication may occur. The phosphate levels exceeded the values admissible for the Salmonidae family in the Raba River below Dobczyce reservoir [18].

In the case of ammonium ions, a considerable division was observed in their average monthly concentrations at individual measuring stations. The highest values were noted above Dobczyce reservoir $\left(0.24-0.78 \mathrm{mg} \cdot \mathrm{dm}^{-3} ;\right.$ Fig. 2 , Table 2$)$, and the lowest - below the reservoir $\left(0.07-0.19 \mathrm{mg} \cdot \mathrm{dm}^{-3}\right)$. The intermediate values were recorded in the reservoir itself $\left(0.06-0.39 \mathrm{mg} \cdot \mathrm{dm}^{-3}\right)$. The exceptions were September and October when ammonia concentrations were higher in the Raba river below the reservoir than in the reservoir itself. The mean annual concentrations of ammonium ions did not exceed the admissible limits for I water class. In the past decade, a decline in the mean annual ammonia concentration has been observed, but it is not statistically significant at the significance level of $p<0.05$. In the Raba River below Dobczyce reservoir, the annual mean values were slightly 
As with Czorsztyn reservoir, it was demonstrated that there is a statistically significant difference $(p<0.01)$ in phosphate content between Dobczyce reservoir and samples collected below and above it, as well as in ammonia concentration lower $\left(0.06-0.14 \mathrm{mg} \cdot \mathrm{dm}^{-3}\right)$ than in the reservoir itself $\left(0.07-0.21 \mathrm{mg} \cdot \mathrm{dm}^{-3}\right)($ Table 3$)$.

Table 3

Results of the statistical analysis of nutrients concentration with the use of the U Mann-Whitney test (the bold values are statistically significant at the level of $p<0.05$ )

\begin{tabular}{|c|c|c|c|c|c|c|c|c|}
\hline Nutrient & Reservoir & $\begin{array}{l}\text { The sum of } \\
\text { the ranks } \\
\text { (reservoir) }\end{array}$ & $\begin{array}{l}\text { The sum of } \\
\text { the ranks } \\
\text { (above } \\
\text { reservoir) }\end{array}$ & $\mathbf{U}$ & $\mathbf{Z}$ & p & $\mathrm{N}$ reservoir & $\begin{array}{c}\mathbf{N} \\
\text { above } \\
\text { reservoir }\end{array}$ \\
\hline \multirow{3}{*}{$\mathrm{NO}_{3}^{-}$} & Dobczyce & 134.0 & 166.0 & 56.0 & -0.895 & 0.371 & 12 & 12 \\
\hline & Klimkowka & 78.0 & 132.0 & 42.0 & -0.425 & 0.671 & 8 & 12 \\
\hline & Czorsztyn & 77.0 & 133.0 & 41.0 & -0.501 & 0.616 & 8 & 12 \\
\hline \multirow{3}{*}{$\mathbf{N H}_{4}^{+}$} & Dobczyce & 81.0 & 213.0 & 3.0 & -3.955 & 0.000 & 12 & 12 \\
\hline & Klimkowka & 136.5 & 94.5 & 16.5 & 2.634 & 0.008 & 9 & 12 \\
\hline & Czorsztyn & 55.0 & 176.0 & 10.0 & -3.091 & 0.002 & 9 & 12 \\
\hline \multirow{3}{*}{$\mathrm{PO}_{4}{ }^{3-}$} & Dobczyce & 84.0 & 216.0 & 6.0 & -3.782 & 0.000 & 12 & 12 \\
\hline & Klimkowka & 102.0 & 108.0 & 30.0 & 1.379 & 0.168 & 8 & 12 \\
\hline & Czorsztyn & 114.0 & 117.0 & 39.0 & 1.030 & 0.303 & 9 & 12 \\
\hline Nutrient & Reservoir & $\begin{array}{l}\text { The sum of } \\
\text { the ranks } \\
\text { (reservoir) }\end{array}$ & $\begin{array}{l}\text { The sum of } \\
\text { the ranks } \\
\text { (below } \\
\text { reservoir) }\end{array}$ & $\mathbf{U}$ & $\mathbf{Z}$ & $\mathbf{p}$ & $\mathrm{N}$ reservoir & $\begin{array}{c}\mathrm{N} \\
\text { below } \\
\text { reservoir }\end{array}$ \\
\hline \multirow{3}{*}{$\mathrm{NO}_{3}^{-}$} & Dobczyce & 122.0 & 178.0 & 44.0 & -1.588 & 0.112 & 12 & 12 \\
\hline & Klimkowka & 59.0 & 151.0 & 23.0 & -1.890 & 0.059 & 8 & 12 \\
\hline & Czorsztyn & 73.0 & 137.0 & 37.0 & -0.810 & 0.418 & 8 & 12 \\
\hline \multirow{3}{*}{$\mathrm{NH}_{4}^{+}$} & Dobczyce & 174.0 & 126.0 & 48.0 & 1.357 & 0.175 & 12 & 12 \\
\hline & Klimkowka & 95.0 & 136.0 & 50.0 & -0.249 & 0.804 & 9 & 12 \\
\hline & Czorsztyn & 76.0 & 155.0 & 31.0 & -1.599 & 0.110 & 9 & 12 \\
\hline \multirow{3}{*}{$\mathrm{PO}_{4}{ }^{3-}$} & Dobczyce & 78.0 & 222.0 & 0.0 & -4.129 & 0.000 & 12 & 12 \\
\hline & Klimkowka & 45.0 & 165.0 & 9.0 & -2.970 & 0.003 & 8 & 12 \\
\hline & Czorsztyn & 153.0 & 78.0 & 0.0 & 3.802 & 0.000 & 9 & 12 \\
\hline
\end{tabular}

\section{Ropa River and Klimkowka reservoir}

The catchment area of the Ropa River mainly consists of agricultural land, which constitutes $54 \%$ of the area (arable land - 25\%). Forests constitute $43 \%$ of the catchment area (Corine Land Cover). As with the Raba and Dunajec, the highest average monthly concentrations of nitrates in the Ropa River (above $5 \mathrm{mg} \cdot \mathrm{dm}^{-3}$ ) were noted in the winter. Average monthly nitrate concentrations were the lowest above Klimkowka reservoir (2.0-5.7 $\left.\mathrm{mg} \cdot \mathrm{dm}^{-3}\right)$, and the highest - below it (3.3-6.3 $\mathrm{mg} \cdot \mathrm{dm}^{-3}$; Fig. 2, Table 2). In the period 2004-2013, the average annual nitrate levels $\left(3.89-5.60 \mathrm{mg} \cdot \mathrm{dm}^{-3}\right)$ recorded below Klimkowka reservoir exceeded the levels recorded in the reservoir tributary $\left(3.29-4.26 \mathrm{mg} \cdot \mathrm{dm}^{-3}\right)$ and in the impoundment itself $\left(2.90-3.66 \mathrm{mg} \cdot \mathrm{dm}^{-3}\right)$. The concentration of nitrates did not exceed $10 \mathrm{mg} \cdot \mathrm{dm}^{3}$. This in the admissible limit value above which the phenomenon of eutrophication in the flowing water may occur [18].

As with the Raba River, the highest average monthly concentrations of phosphates were observed below Klimkowka reservoir. The values were up to twice as high as the levels recorded in the Ropa River above the reservoir and in the reservoir itself. The changes of the mean annual values in the period investigated ranged from 
$0.02-0.23 \mathrm{mg} \cdot \mathrm{dm}^{-3}$. The phosphate concentrations in the Ropa River in all measuring points did not exceed the admissible limits above which eutrophication in the flowing water may occur [18].

By contrast with the remaining reservoirs, the mean monthly concentrations of ammonia in Klimkowka reservoir in the period investigated $\left(0.05-0.22 \mathrm{mg} \cdot \mathrm{dm}^{-3}\right)$ slightly exceeded the levels recorded in the inflowing water $\left(0.04-0.17 \mathrm{mg} \cdot \mathrm{dm}^{-3}\right.$; Fig. 2, Table 2). Regarding Klimkowka reservoir, no regularities were found. In all measuring points, ammonia concentrations did not exceed the admissible limits for I water class. Due to the fragmentary character of the measuring series, it is difficult to determine unequivocal regularities in the dynamics of ammonia concentration in the period 2004-2013.

The levels of nutrients in all measuring points did not exceed the admissible limit values for water to enable fish dwelling [17].

As with the remaining reservoirs, the statistical analysis demonstrated that there is a statistically significant difference $(p<0.01)$ in phosphate concentration between Klimkowka reservoir and samples collected below it, as well as in ammonium ion concentration in the reservoir and the measuring point above it (Table 3).

\section{Conclusions}

The analysis of nutrient concentration in selected reservoirs and in rivers above and below them was based on a long-term series of measurements. The results obtained allow the following conclusions to be drawn:

1. The reservoirs investigated generally contribute to an increase in nitrates in the rivers flowing below the reservoirs in individual months. The content of nitrates demonstrates an upward tendency in the winter and a downward tendency in the summer. In the period investigated, a decline in nitrate concentration was observed in the Dunajec River and in the Czorsztyn-Sromowce Wyzne reservoir complex. Such a tendency was not observed in the remaining rivers and impoundments.

2. The phosphate concentrations in the surface water investigated show considerable dynamics over a year. The concentration of phosphates was lower in the spring, after the growing season begins. In the summer, however, an increase in their amount was observed, which might contribute to an increase in the fertility of reservoirs. The role of reservoirs in shaping phosphate levels is not as evident as in the case of nitrates. In the Raba and Ropa Rivers, the highest phosphate concentrations were observed below the reservoirs, which is probably associated with inflow of sewage and/or mineral fertilisers from agricultural lands. The phosphate concentration was higher in Czorsztyn reservoir than in the Dunajec River. This reservoir, however, did not contribute to an increase in the amount of phosphates in the river flowing out of it.

3. Ammonia levels in Dobczyce and Czorsztyn reservoirs were lower than in the water supplying these impoundments. This correlation was not so evident in the measuring points localised below these reservoirs. The Dunajec River below the Czorsztyn-Sromowce Wyzne reservoir complex showed greater concentrations of ammonia than water in the reservoir itself. An inverse regularity was observed in Dobczyce reservoir where the level of this nutrient was higher than in the Raba River below the reservoir. In the Ropa River and Klimkowka reservoir, the dynamics of ammonia levels was less diversified, but it can be observed that this reservoir was characterised by slightly higher ammonia levels than the inflowing water. This 
contributed to a slight increase in the amount of this nutrient in the river below the dam.

4. The concentrations measured in the rivers and storage reservoirs investigated generally do not exceed the admissible limit values above which the phenomenon of eutrophication may occur [18]. Due to the levels of ammoniacal nitrogen and phosphates, the water tested in the period of the investigation created sufficient conditions for the Salmonidae and Cyprinidae fish [17].

5. The water in the reservoirs and rivers discussed shows a very high resistance to acidification. This is demonstrated by the values of ANCaq indicator which exceeded $200 \mu \mathrm{Eq} \cdot \mathrm{dm}^{-3}$.

6. Based on the statistical analysis conducted with the use of the non-parametric U Mann-Whitney test, it was concluded that there is a statistically significant difference $(p<0.01)$ in phosphate content between all the reservoirs and samples collected below them. It was also demonstrated that the differences in the content of ammonium ions between the reservoirs and sites localised above them are statistically significant. It must be emphasised, however, that no statistically significant differences were found regarding the content of nitrate ions in any of the measuring points.

To sum up, it may be concluded that the role of storage reservoirs in shaping concentrations of nutrients in the Carpathian rivers is not explicit. The reservoirs are merely one of numerous factors that contribute to nutrient levels in the water of the mountains rivers. In the light of the analysis of nutrient concentrations in the surface water tested, it may be concluded that the reservoirs do not cause a clear and permanent deterioration of river water quality.

\section{References}

[1] Palmer RW, O'Keeffe JH. Hydrobiologia. 1990;202:71-83. DOI: 10.1007/BF02208128.

[2] Dumnicka E, Kasza H, Kownacki A, Krzyżanek E, Kuflikowski T. Hydrobiologia.1988;169:183-191. DOI: 10.1007/BF00007309.

[3] Czamara W, Czamara A, Wiatkowski M. The use of pre-dams with plant filters to improve water quality in storage reservoirs. Archives Environ Protect. 2008;34:79-89. www.researchgate.net/publication/ 283137175_The_use_of_pre-dams_with_plant_filters_to_improve_water_quality_in_storage_reservoirs.

[4] Rigacci LN, Giorgi AD, Vilches CS, Ossana NA, Salibián A. Environ Monit Assess. 2013;185:9161-9168. DOI: $10.1007 / \mathrm{s} 10661-013-3243-\mathrm{y}$.

[5] Wiatkowski M, Paul L. Surface water quality assessment in the Troja river catchment in the context of Wlodzienin reservoir construction. Pol J Environ Stud. 2009;18:923-929. http://www.pjoes.com/pdf/ 18.5/923-929.pdf.

[6] Duras J, Hejzlar J. Inter Rev Hydrob. 2001;86:585-60. DOI: 10.1002/1522-2632(200110).

[7] Hart BT, van Dok W, Djuangsih N. Water Res. 2002;36:2152-2160. DOI: 10.1016/S0043-1354(01)00428-6.

[8] Alaoui Mhamdi B, Azzouzi A, Alaoui Mhamdi M, Sime-Ngando T. Water Resour Manage. 2007;21:983-995. DOI: 10.1007/s11269-006-9068-5.

[9] Ideva RJ, Machiwa J, Schiemer F, Hein T. Afr J Aquat Sci. 2008;33:181-188. DOI: 10.2989/AJAS.2008.33.2.11.508.

[10] Schoch AL, Schilling KE, Chan KS. Adv Water Resour. 2009;32:1197-1205. DOI: 10.1016/j.advwatres.2009.04.002.

[11] Kõiv T, Nõges T, Laas A. Hydrobiologia. 2011;660:105-115. DOI: 10.1007/s10750-010-0411-8.

[12] Grigoreva IL, Komissarov AB. Water Resour. 2014;41:280-293. DOI: 10.1134/S0097807814030087.

[13] Viviroli D, Weingartner R. Hydrol Earth Syst Sci. 2004;8:1017-1030. DOI: 10.5194/hess-8-1017-2004.

[14] Wiejaczka Ł, Kijowska-Strugała M. Water Environ J. 2015;29,2:277-287.DOI: 10.1111/wej.12082.

[15] Soja R, Wiejaczka Ł. Water Environ J. 2014;28,4:473-482. DOI: 10.1111/wej.12059.

[16] Directive 2008/105/EC of the European Parliament and of the Council of 16 December 2008 on environmental quality standards in the field of water policy. www.eurlex.europa.eu/LexUriServ/LexUriServ.do?uri=OJ:L:2008:348:0084:0097:en:PDF. 
[17] Rozporządzenie Ministra Środowiska z dnia 4 października 2002 r. w sprawie wymagań, jakim powinny odpowiadać wody śródlądowe będące środowiskiem życia ryb w warunkach naturalnych. DzU 2002, $\mathrm{Nr}$ 176, poz. 1455 (Regulation of the Minister of the Environment of 4 October 2002 on requirements to be met by inland waters being the habitat of fish in natural conditions, Journal of Acts of 2002, No 176, item 1455). www.dziennikustaw.gov.pl/du/2002/s/176/1455.

[18] Rozporządzenie Ministra Środowiska z dnia 23 grudnia 2002 r. w sprawie kryteriów wyznaczania wód wrażliwych na zanieczyszczenie związkami azotu ze źródeł rolniczych, DzU 2002, Nr 241, poz. 2093 (The Regulation of the Minister of the Environment of 23 December 2002 on criteria for designation of water sensitive to pollution with nitrogen compounds from agricultural sources, Journal of Acts of 2002, No 241, item 2093). www.dziennikustaw.gov.pl/du/2002/s/241.

[19] Kozlowski R, Jozwiak M. Ecol Chem Eng S. 2013;20(1):41-54. DOI: 10.2478/eces-2013-0003.

[20] Poor CJ, McDonnell JJ. J Hydrol. 2007;332:54-68. DOI:10.1016/j.jhydrol.2006.06.022.

[21] Balcerzak W. The protection of reservoir water against the eutrophication process. Pol J Environ Stud. 2006;15(6):837-844. www.6csnfn.pjoes.com/pdf/15.6/837-844.pdf.

[22] Kopacz M, Twardy S. The land use changes in agricultural areas between 1980 and 2005 with particular emphasis on permanent grasslands - an example of the upper Raba River basin. J Water Land Develop. 2011;15:19-28. www.itp.edu.pl/wydawnictwo/journal/15_2011/artykuly/Kopacz\%20Twardy.pdf. 